\title{
Effect of Reduced Dietary Copper Levels Sourced from Organic and Nanoparticles Forms on Performance and Nutrient Utilization in Giriraja Birds
}

\author{
Noor Aminullah¹, T.M. Prabhu1, Jaya Naik², B.N. Suresh³ ${ }^{3}$ N. Suma ${ }^{1}$
}

10.18805/IJAR.B-4538

\begin{abstract}
Background: Copper $(\mathrm{Cu})$ is an essential trace mineral for growth, production and health of poultry. Due to its poor absorption from inorganic source which is common supplemental form, large amount of $\mathrm{Cu}$ is excreted in the excreta. This experiment was conducted to assess the bioavailability of $\mathrm{Cu}$ from organic and nano sources at lower level of supplementation to reduce the excretion level without compromising the growth performance of chicken.

Methods: A total of 420-day-old Giriraja chicks were randomly assigned to 7 treatment groups having 4 replicates each (15 chicks per replicate). The basal diets of both chick (0-6 weeks) and grower phases (7-10 weeks) were supplemented with 20 and $30 \mathrm{ppm}$ of $\mathrm{Cu}$ from inorganic source as control $\left(T_{1}\right)$, the groups $T_{2}, T_{3}$ and $T_{4}$ supplemented with 100,75 and $50 \%$ of control from organic $\mathrm{Cu}, T_{5}, T_{6}$ and $T_{7}$ treatment diets supplemented with 75,50 and $25 \%$ of control from Cu nanoparticles, respectively.

Result: The grower phase and cumulative body weight gain was significantly $(p<0.05)$ higher in $T_{2}$ compared to $T_{1}, T_{6}$ and $T_{7}$ groups, while the feed intake in chick phase was lower in $T_{2}, T_{5}$ and $T_{7}$ groups as compared to $T_{1}, T_{3}, T_{4}$ and $T_{6}$. The chick phase feed conversion ratio was significantly $(p<0.05)$ better in $T_{2}$ and $T_{5}$ groups compared to $T_{1}, T_{3}, T_{4}, T_{6}$ and $T_{7}$, whereas the cumulative $F C R$ was better in $T_{2}$ and $T_{5}$ compared to $T_{6}$ and $T_{7}$ groups, while it was not affected during grower phase. The dry matter and crude protein metabolizability were significantly $(p<0.05)$ higher in $T_{2}$ and $T_{5}$, the organic matter and ether extract metabolizability was higher only in $T_{5}$. The crude fiber and nitrogen free extract was not affected by the treatment diets. Nitrogen excretion was significantly $(p<0.05)$ lower and its retention was higher in $\mathrm{T}_{2}$ and $\mathrm{T}_{5}$ treatment groups but was comparable with control. The $\mathrm{Cu}$ excretion through excreta was significantly $(p<0.05)$ higher and its retention was lower in control as compared to all dietary treatments. Hence, it was concluded that the $\mathrm{Cu}$ supplementation from organic or nanoparticles form can be reduced by 50 and $75 \%$ of standard, respectively without compromising the growth performance of birds and nutrient digestibility of diets.
\end{abstract}

Key words: Copper, Giriraja, Nanoparticles, Organic mineral.

\section{INTRODUCTION}

Copper $(\mathrm{Cu})$ is an essential inorganic trace element required for growth, production, reproduction and health of animals and birds (Collins et al., 2010). It serves as a cofactor for more than 200 enzymes such as cytochrome oxidase, lysyl oxidase, ceruloplasmin and superoxide dismutase in animal body (Wu et al., 2015). However, the Cu content in major feed ingredients included in poultry diet are unable to meet $\mathrm{Cu}$ requirement of birds hence, its supplementation is necessary to maintain the productivity and health of the birds. Further, the absorption and utilization of $\mathrm{Cu}$ from conventionally used inorganic sources is poor (Scott et al., 2018). Hence, a large amount of $\mathrm{Cu}$ is excreted and its accumulation in the environment causes toxicity in plants and grazing animals (Ferket et al., 2002). Therefore, biotechnological interventions are essential to increase the $\mathrm{Cu}$ bioavailability and absorption and reduce its environmental pollution.

It is reported that the organic source of Cu can improve its utilization and minimize the level in the excreta and environmental pollution (Nollet et al., 2007) due to its better absorption and metabolism properties. Nollet et al. (2007)
${ }^{1}$ Department of Animal Nutrition, Veterinary College, Karnataka Veterinary, Animal and Fisheries Sciences University, Bengaluru560 024, Karnataka, India.

${ }^{2}$ Department of Poultry Science, Veterinary College, Karnataka Veterinary, Animal and Fisheries Sciences University, Bengaluru560 024, Karnataka, India.

${ }^{3}$ Department of Livestock Farm Complex, Veterinary College, Karnataka Veterinary, Animal and Fisheries Sciences University, Bengaluru-560 024, Karnataka, India.

Corresponding Author: Aminullah Noor, Department of Animal Nutrition, Veterinary College, Karnataka Veterinary, Animal and Fisheries Sciences University, Bengaluru-560 024, Karnataka, India. Email: aminullah.noor18@gmail.com

How to cite this article: Aminullah, N., Prabhu, T.M., Naik, J., Suresh, B.N. and Suma, N. (2022). Effect of Reduced Dietary Copper Levels Sourced from Organic and Nanoparticles Forms on Performance and Nutrient Utilization in Giriraja Birds. Indian Journal of Animal Research. 56(1): 58-64. DOI: 10.18805/IJAR.B-4538.

Submitted: 22-05-2021 Accepted: 03-08-2021 Online: 31-08-2021 
Effect of Reduced Dietary Copper Levels Sourced from Organic and Nanoparticles Forms on Performance and Nutrient...

also reported no differences in performance of broilers fed diet contained reduced levels of organic chelated $\mathrm{Cu}$ but significantly $(p<0.05)$ lower fecal $\mathrm{Cu}$ excretion rates. Similarly, nano particles (NP) of Cu having large surface-tovolume ratio, higher bioavailability and less antagonism with other minerals are also better alternatives. As per the current literature available, the Cu-NP is better than its bulk form in enhancing performance of animals (Al-Bairuty et al., 2016). The organic and NP of $\mathrm{Cu}$ enhance growth performance, nutrient utilization, reduce pathogen load and improves health of breeder hens (Raje et al., 2018). The dietary Cu was reduced to 50 and $25 \%$ of control from organic and NP sources, respectively in Swarnadhara breeder hens without affecting egg production, its quality and hatchability (Aminullah et al., 2021). However, such studies in other improved breeds of birds on growth performance and nutrient utilization are lacking. Hence, the present study was planned to find out the most biologically effective form of $\mathrm{Cu}$ with higher efficiency and to reduce its supplementation and excretion level without compromising growth performance and nutrients utilization in Giriraja chicken.

\section{MATERIALS AND METHODS}

All the procedures with regards to the management and care of the birds followed during the trial were approved by the Institutional Animal Ethics Committee of the University having approval number VCH/IAEC/2020/01, dated 03.03.2020.

A genotype akin to country fowl named Giriraja, a multicolored dual purpose cross breed chicken developed and released by Veterinary College, KVAFSU, Bengaluru for rural scavenging conditions were used. A total of 420-a day-old Giriraja chicks were wing banded and randomly assigned to seven treatment groups of four replicates with 15 chicks in each replicate maintained for 10 weeks of study period under deep litter system with all standard managemental practices. All treatment groups received respective isonitrogenous and iso-caloric diets according to their growth stage viz., chick' diet from 0 to 6 weeks and grower diet from 7 to 10 weeks of age. The daily required amount of feed was weighed and offered replicate wise and recorded. Water was provided ad libitum during the trial period. The experiment was conducted at Veterinary College, Hebbal,
Bengaluru, Karnataka, India, located at $13.030 \mathrm{~N}$ and $77.600 \mathrm{E}$ in 2020 for 10 weeks of time period.

The $\mathrm{Cu}$ nano particles were procured from M/s Matrix Nano Pvt Ltd., New Delhi and inorganic copper sulphate and organic copper as copper proteinate from M/s ZeusBiotech Pvt. Ltd., Mysuru, Karnataka. The particle size of Cu-NPs was $50-80 \mathrm{~nm}$ with $98 \%$ purity. The basal diets were formulated as per ICAR (2013) nutrient specifications except $\mathrm{Cu}$. The basal diet was supplemented with $20 \mathrm{ppm} \mathrm{Cu}$ in chick phase and $30 \mathrm{ppm}$ in grower phase from inorganic $\mathrm{CuSO}_{4}$ as control. The treatment diets for chick and grower phases were supplemented with different levels of $\mathrm{Cu}$ from organic and NP sources as described in Table 1. The ingredient and chemical composition of basal diets is presented in Table 2. The concentration of $\mathrm{Cu}$ in experimental diets (Table 1) was estimated using ICP-OES (Perkin Elmer Optima 8000).

After an adaptation period of 3 days during terminal week of the trial, a total excreta collection method involving two birds in each replicate housed in cage for 3 days was employed to study the bioavailability of different sources of $\mathrm{Cu}$ and other nutrients utilization. The samples of feed offered, residue left and excreta voided were analyzed for proximate composition. The nitrogen retained in the body was calculated as the difference between nitrogen intake and nitrogen excreted and expressed as gram per day per kg metabolic body weight $\left(\mathrm{W}^{0.75}\right)$ or per cent of intake nitrogen.

\section{RESULTS AND DISCUSSION}

The cumulative body weight gain (BWG), feed intake (FI) and feed conversion ratio (FCR) of birds under different treatments is presented in Table 3 . In the study, the BW values of the chick's stage $\left(0-6^{\text {th }}\right.$ week) indicated no effect of source and inclusion levels of $\mathrm{Cu}$ on chicks BWG. In contrast, during grower phase $\left(7-10^{\text {th }}\right.$ week $)$ and cumulatively i.e. $1-10^{\text {th }}$ week, the BWG was significantly $(p<0.05)$ higher in $T_{2}$ as compared $T_{6}$ and $T_{7}$ and control groups. The improved BWG in $\mathrm{T}_{2}$ treatment group was due to higher $(100 \%)$ dose and better bioavailability of copper proteinate as compared to inorganic $\mathrm{CuSO}_{4}$ (Das et al., 2010). Cu plays important role in poultry growth performance which is attributed to its antimicrobial properties that can improve

Table 1: Description of experimental groups and dietary total $\mathrm{Cu}$ content.

\begin{tabular}{lcccc}
\hline Tr. no. & Copper source and $\%$ & \multicolumn{2}{c}{ Supplemented Cu (ppm) } & \multicolumn{2}{c}{ Analyzed dietary Cu content (ppm) } \\
\cline { 2 - 5 } & standard recommendation & Chick diet & Grower diet & Chick diet \\
\hline $\mathrm{T}_{1}$ & Inorganic Cu (100) & 20 & 30 & 27.94 \\
$\mathrm{~T}_{2}$ & Organic Cu (100) & 20 & 30 & 27.62 \\
$\mathrm{~T}_{3}$ & Organic Cu (75) & 15 & 22.5 & 22.65 \\
$\mathrm{~T}_{4}$ & Organic Cu (50) & 10 & 15 & 17.70 \\
$\mathrm{~T}_{5}$ & Cu-NP (75) & 15 & 22.5 & 22.73 \\
$\mathrm{~T}_{6}$ & Cu-NP (50) & 10 & 15 & 23.52 \\
$\mathrm{~T}_{7}$ & Cu-NP (25) & 5 & 7.5 & 28.41 \\
\hline
\end{tabular}

Organic $\mathrm{Cu}=$ Copper proteinate, $\mathrm{Cu}-\mathrm{NP}=$ Copper nanoparticles. 
the intestinal health (Usman et al., 2013). In previous reports, the effect of $\mathrm{Cu}$ on growth rate was attributed to its function on improved growth hormone axis (Yang et al., 2011) and hypothalamic appetite regulation expression in weanling pigs (Zhu et al., 2011).

It is hypothesized that Cu-NP due to its novel properties such as large surface area, higher reactivity and better utilization can improve the growth performance and reduce dietary supplementation and excretion rate as well. In the present study, however there is no improved BWG due to Cu-NP, but reduction even up to $75 \%$ level had no adverse effect on growth performance as the body weight was comparable to control. The findings are in accordance with those of Sawosz et al. (2018) and Kozlowski et al. (2018) who supplemented Cu-NP reduced by 75 and $80 \%$ in broilers and turkey, respectively without observing any reduction in growth performance. The reason is that Cu-NP can more eûectively penetrate cell membrane barriers and can be rapidly distributed independent of the blood circulation (Anjum et al., 2016).

Table 2: Ingredient and chemical composition of basal diets.

\begin{tabular}{|c|c|c|}
\hline Ingredients $(\mathrm{kg})$ & $\begin{array}{l}\text { Chick diet } \\
\text { (0-6 week) }\end{array}$ & $\begin{array}{l}\text { Grower diet } \\
\text { (7-10 week) }\end{array}$ \\
\hline Yellow maize & 61.30 & 57.00 \\
\hline Soybean meal & 34.50 & 24.36 \\
\hline De-oiled rice bran & - & 15.00 \\
\hline Dicalcium phosphate & 1.55 & - \\
\hline Mineral mixture-without copper* & 2.00 & 3.00 \\
\hline Bacitracin methylene disalicylate & 0.03 & 0.03 \\
\hline Salinomycin & 0.05 & 0.05 \\
\hline Vitamin premix** & 0.025 & 0.03 \\
\hline Vitamin B complex ${ }^{* * *}$ & 0.035 & 0.04 \\
\hline DL-Methionine & 0.10 & 0.08 \\
\hline Hepatocare & 0.10 & 0.10 \\
\hline Common salt & 0.31 & 0.31 \\
\hline Total & 100.00 & 100.00 \\
\hline \multicolumn{3}{|l|}{ Chemical composition } \\
\hline $\mathrm{ME}(\mathrm{kcal} / \mathrm{kg})^{\mathrm{a}}$ & 2881 & 2795 \\
\hline Crude protein & 21.20 & 18.34 \\
\hline Calcium & 1.09 & 1.10 \\
\hline Total phosphorus & 0.86 & 0.65 \\
\hline Lysine & 1.17 & 0.97 \\
\hline Methionine $^{a}$ & 0.46 & 0.41 \\
\hline Selenium $(p p m)^{a}$ & 0.25 & 0.27 \\
\hline Zinc (ppm) & 105 & 124 \\
\hline $\mathrm{Fe}(\mathrm{ppm})$ & 114 & 127.09 \\
\hline Mn (ppm) & 94 & 127 \\
\hline Cu (ppm) & 7.97 & 8.27 \\
\hline
\end{tabular}

${ }^{*}$ Contains: Ca-32\%, P-9\%, Fe-2000 ppm, I-0.01\%, Mn-0.4\% and $\mathrm{Zn}-0.4 \%,{ }^{* *}$ Each gram contains: Vitamin A-82500 IU, $\mathrm{B}_{2}-50 \mathrm{mg}$, $\mathrm{D}_{3}-12000 \mathrm{IU}$ and $\mathrm{K}-10 \mathrm{mg} .{ }^{* * *}$ Each gram contains: Vitamin $\mathrm{B}_{1}-4 \mathrm{mg}$, $\mathrm{B}_{6}-8 \mathrm{mg}, \mathrm{B}_{12}-40 \mathrm{mg}, \mathrm{E}-40 \mathrm{mg}$, Pantothenate-40 mg, Niacin-60 mg. ${ }^{a}$ Calculated value.
No effect of dietary treatments was observed on feed intake during grower phase (7-10 weeks) as well as cumulative period i.e. 1-10 week. In the chick's stage, the feed intake was significantly lower in $\mathrm{T}_{2}$ and $\mathrm{T}_{5}$ as compared to all other treatment groups except of $T_{7}$. Despite of reduced feed intake in $T_{2}$ and $T_{5}$ treatment groups, the BWG was not affected resulting in significant $(p<0.05)$ improvement in feed conversion ratio. During grower phase there was no sighnificant difference in feed consumption among the treatment groups.

$\mathrm{Cu}$ plays important role in cytochrome $\mathrm{C}$ oxidase that contributes for efficient production of adenosine triphosphate and energy metabolism (Wu et al., 2015). Therefore, the better feed conversion ratio at higher $\mathrm{Cu}$ level receiving groups $\left(T_{2}\right.$ and $\left.T_{5}\right)$ reflects improved energy and nutrients utilization of the diet.

The improved gut health due to antimicrobial properties of Cu (Usman et al., 2013) also might have contributed for the better feed conversion ratio. Ramesh (2014) reported that dietary inclusion of $\mathrm{Cu}-\mathrm{NP}$ at 25 to $50 \%$ of requirement can reduce feed intake without compromising the feed conversion ratio in laying hens. However, Wen et al. (2019) reported no significant effect of 20 and $40 \mathrm{ppm} \mathrm{CuSO}_{4}$ or $\mathrm{Cu}$-methionine on feed intake and feed conversion ratio in broilers.

The metabolizability of various nutrients presented in Table 4 indicates significant $(p<0.05)$ increase of DM and $\mathrm{CP}$ metabolizability due to $\mathrm{Cu}$ supplementation at $30 \mathrm{ppm}$ (organic) and $22.5 \mathrm{ppm}$ (NP). The metabolizability of OM and EE was higher $(p<0.05)$ at $22.5 \mathrm{ppm}$ Cu-NP inclusion as compared to all other groups except for $\mathrm{T}_{2}$ while CF and NFE metabolizability remained unaffected. The results revealed that the reduced dietary $\mathrm{Cu}$ levels sourced from organic or NP has no adverse effect on nutrient utilization. Meanwhile, the highest $\mathrm{Cu}$ levels i.e. $100 \%$ from organic and $75 \%$ from NP sources as compared to standard $\mathrm{CuSO}_{4}$ were also optimum for nutrient utilization of the diet.

The reports suggesting effective utilization of nutrients due to $\mathrm{Cu}$ antimicrobial properties (Usman et al., 2013), better digestibility of DM, OM and NFE (Gonzales et al., 2009) and greater bioavailability of Cu organic (Nollet et al., 2008) and NP forms (Tamilvanan et al., 2014) are supportive of the finding of the present study. The improved fat utilization can be attributed to the enhanced lipase and phospholipase activities in small intestine with $\mathrm{Cu}$ supplementation (Das et al., 2010). The improved nutrient utilization at $22.5 \mathrm{ppm}$ Cu-NP inclusion level confirms its better efficiency as compared to $30 \mathrm{ppm}$ inorganic $\mathrm{CuSO}_{4}$. However, the results are in contrast to the findings of Sarvestani et al. (2016) who reported no significant effect of 100 ppm Cu-NP dietary inclusion on nutrients digestibility in broilers.

Nitrogen balance of experimental birds is presented in Table 5. The source and level of $\mathrm{Cu}$ had no effect on total nitrogen intake $\left(\mathrm{g} / \mathrm{kg} \mathrm{W} \mathrm{W}^{0.75} /\right.$ day), while significantly $(\mathrm{p}<0.05)$ lower excretion and higher $(p<0.05)$ retention $\left(g / \mathrm{kg} \mathrm{W}^{0.75} /\right.$ day or per cent of $\mathrm{N}$ intake) of nitrogen observed at $100 \%$ 


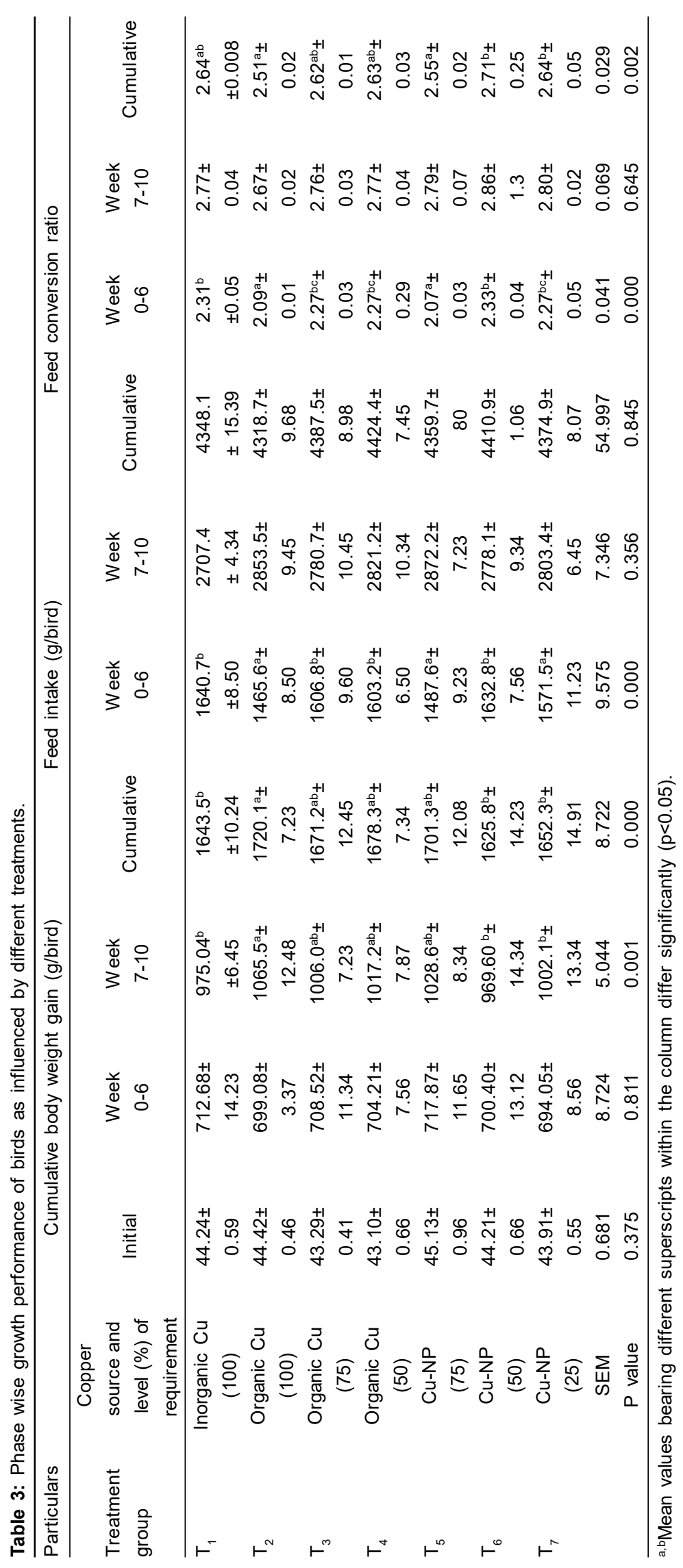


Effect of Reduced Dietary Copper Levels Sourced from Organic and Nanoparticles Forms on Performance and Nutrient...

inclusion level from organic and $75 \%$ from NP form of $\mathrm{Cu}$ as compared to other dietary treatments, however the values were comparable to control.

In the present study, the inclusion of organic (100\%) and $\mathrm{NP}(75 \%)$ form of $\mathrm{Cu}$ in relation to $\mathrm{CuSO}_{4}$ during grower phase was optimum for nitrogen and other nutrients metabolizability which reflect its greater utilization efficiency. The improved nitrogen retention could be speculated that Cu-NP supplementation boost hormone and growth factors in chicken (Das et al., 2010), thereby enhancing protein synthesis and deposition in tissue. The better nitrogen retention can also be associated to the improved energy (OM and EE) metabolizability that can be attributed to better gut health of the chicken. Scott et al. (2016) also reported significantly improved energy and nitrogen utilization and reduction in nitrogen excretion at $20 \mathrm{ppm} \mathrm{Cu-NP}$ than $\mathrm{CuSO}_{4}$ in drinking water. In the present study, however, with reduced $\mathrm{Cu}$ supplemental level from organic or NP source, the nitrogen retention and excretion was not adversely affected by the treatment diets as compared to control.

$\mathrm{Cu}$ balance in the body has been presented in Table 6; indicates that its excretion in dropping in $\mathrm{mg}$ per $\mathrm{kg} \mathrm{W}^{0.75}$ per

Table 4: Metabolizability of various nutrients (\%) of experimental diets.

\begin{tabular}{lccccccc}
\hline $\begin{array}{l}\text { Treatment } \\
\text { group }\end{array}$ & $\begin{array}{c}\text { Copper source } \\
\text { (\% of requirement) }\end{array}$ & $\begin{array}{c}\text { Dry } \\
\text { matter }\end{array}$ & $\begin{array}{c}\text { Organic } \\
\text { matter }\end{array}$ & $\begin{array}{c}\text { Crude } \\
\text { protein }\end{array}$ & $\begin{array}{c}\text { Ether } \\
\text { extract }\end{array}$ & $\begin{array}{c}\text { Crude } \\
\text { fiber }\end{array}$ & $\begin{array}{c}\text { Nitrogen } \\
\text { free extract }\end{array}$ \\
\hline $\mathrm{T}_{1}$ & Inorganic Cu (100) & $64.37^{\mathrm{b}} \pm 0.70$ & $66.93^{\mathrm{b}} \pm 1.02$ & $64.74^{\mathrm{ab}} \pm 4.17$ & $76.56^{\mathrm{b}} \pm 2.62$ & $22.91 \pm 3.03$ & $70.29 \pm 0.12$ \\
$\mathrm{~T}_{2}$ & Organic Cu (100) & $69.46^{\mathrm{a}} \pm 1.16$ & $70.44^{\mathrm{ab}} \pm 1.46$ & $72.56^{\mathrm{a}} \pm 3.12$ & $83.38^{\mathrm{ab}} \pm 2.37$ & $21.13 \pm 2.21$ & $72.55 \pm 2.27$ \\
$\mathrm{~T}_{3}$ & Organic Cu (75) & $66.97^{\mathrm{b}} \pm 1.33$ & $68.76^{\mathrm{b}} \pm 1.39$ & $62.81^{\mathrm{ab} \pm 1.50}$ & $74.48^{\mathrm{b} \pm 3.48}$ & $22.78 \pm 1.91$ & $73.51 \pm 2.21$ \\
$\mathrm{~T}_{4}$ & Organic Cu (50) & $65.87^{\mathrm{b}} \pm 0.47$ & $68.34^{\mathrm{b}} \pm 0.45$ & $62.22^{\mathrm{ab}} \pm 2.70$ & $77.65^{\mathrm{b}} \pm 3.20$ & $22.54 \pm 1.96$ & $72.99 \pm 1.08$ \\
$\mathrm{~T}_{5}$ & Cu-NP (75) & $70.30^{\mathrm{a}} \pm 1.00$ & $73.62^{\mathrm{a}} \pm 0.44$ & $74.21^{\mathrm{a}} \pm 2.19$ & $89.72^{\mathrm{a}} \pm 2.74$ & $23.06 \pm 1.86$ & $74.18 \pm 1.77$ \\
$\mathrm{~T}_{6}$ & Cu-NP (50) & $67.99^{\mathrm{b}} \pm 1.37$ & $68.59^{\mathrm{b}} \pm 1.44$ & $61.19^{\mathrm{b}} \pm 3.23$ & $76.63^{\mathrm{b}} \pm 0.77$ & $20.57 \pm 1.68$ & $73.83 \pm 1.89$ \\
$\mathrm{~T}_{7}$ & Cu-NP (25) & $66.40^{\mathrm{b} \pm 0.39}$ & $70.19^{\mathrm{b}} \pm 0.36$ & $65.53^{\mathrm{ab} \pm 1.93}$ & $75.25^{\mathrm{b}} \pm 2.54$ & $19.85 \pm 1.45$ & $72.11 \pm 0.89$ \\
& SEM & 1.060 & 1.123 & 3.039 & 2.844 & 2.082 & 1.753 \\
& P value & 0.006 & 0.006 & 0.019 & 0.006 & 0.841 & 0.697 \\
\hline
\end{tabular}

a,b Mean values bearing different superscripts within the column differ significantly $(p<0.05)$.

Table 5: Intake, excretion and retention of nitrogen under different treatments.

\begin{tabular}{|c|c|c|c|c|c|c|}
\hline $\begin{array}{l}\text { Treatment } \\
\text { group }\end{array}$ & $\begin{array}{c}\text { Copper source } \\
\text { (\% of requirement) }\end{array}$ & $\begin{array}{c}\text { Intake } \\
\left(\mathrm{g} / \mathrm{kg} \mathrm{W}^{0.75} / \mathrm{d}\right)\end{array}$ & $\begin{array}{l}\text { Excretion } \\
\left(\mathrm{g} / \mathrm{kg} \mathrm{W} \mathrm{W}^{0.75} / \mathrm{d}\right)\end{array}$ & $\begin{array}{c}\text { Excretion } \\
(\%)\end{array}$ & $\begin{array}{c}\text { Retention } \\
\left(\mathrm{g} / \mathrm{kg} \mathrm{W}^{0.75} / \mathrm{d}\right)\end{array}$ & $\begin{array}{l}\text { Retention } \\
(\%)\end{array}$ \\
\hline$\overline{\mathrm{T}_{1}}$ & Inorganic $\mathrm{Cu}(100)$ & $2.69 \pm 0.13$ & $0.93^{\mathrm{ab}} \pm 0.07$ & $35.25^{\mathrm{ab}} \pm 4.19$ & $1.76^{\mathrm{b}} \pm 0.18$ & $64.74^{\mathrm{ab}} \pm 4.17$ \\
\hline $\mathrm{T}_{2}$ & Organic Cu (100) & $2.63 \pm 0.08$ & $0.72^{a} \pm 0.07$ & $27.66^{\mathrm{ab}} \pm 3.35$ & $1.91^{\mathrm{a}} \pm 0.14$ & $72.34^{\mathrm{ab}} \pm 3.35$ \\
\hline $\mathrm{T}_{3}$ & Organic Cu (75) & $2.71 \pm 0.11$ & $1.01^{b} \pm 0.07$ & $37.18^{\mathrm{ab}} \pm 1.50$ & $1.69^{b} \pm 0.05$ & $62.81^{\mathrm{ab}} \pm 1.50$ \\
\hline $\mathrm{T}_{4}$ & Organic Cu (50) & $2.73 \pm 0.09$ & $1.03^{b} \pm 0.10$ & $37.78^{\mathrm{ab}} \pm 2.70$ & $1.68^{\mathrm{b}} \pm 0.02$ & $62.22^{\mathrm{ab}} \pm 2.71$ \\
\hline $\mathrm{T}_{5}$ & Cu-NP (75) & $2.71 \pm 0.09$ & $0.69^{a} \pm 0.63$ & $25.78^{\mathrm{a}} \pm 2.19$ & $2.02^{a} \pm 0.11$ & $74.21^{\mathrm{a}} \pm 2.19$ \\
\hline $\mathrm{T}_{6}$ & Cu-NP (50) & $2.49 \pm 0.16$ & $0.95^{\mathrm{ab}} \pm 0.02$ & $38.32^{\mathrm{b}} \pm 2.14$ & $1.54^{\mathrm{b}} \pm 0.17$ & $61.68^{b} \pm 3.27$ \\
\hline \multirow[t]{3}{*}{$\mathrm{T}_{7}$} & Cu-NP (25) & $2.58 \pm 0.08$ & $0.88^{\mathrm{ab}} \pm 0.03$ & $34.46^{\mathrm{ab}} \pm 1.92$ & $1.69^{b} \pm 0.09$ & $65.53^{\mathrm{ab}} \pm 1.93$ \\
\hline & SEM & 0.108 & 0.134 & 2.978 & 3.063 & 0.071 \\
\hline & $\mathrm{P}$ value & 0.731 & 0.009 & 0.020 & 0.018 & 0.020 \\
\hline
\end{tabular}

a,bMean values bearing different superscripts within the column differ significantly $(p<0.05)$.

Table 6: Intake, excretion and retention of copper under different treatments.

\begin{tabular}{|c|c|c|c|c|c|c|}
\hline $\begin{array}{l}\text { Treatment } \\
\text { group }\end{array}$ & $\begin{array}{l}\text { Copper source with } \\
\text { requirement level \% }\end{array}$ & 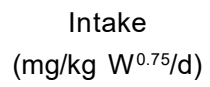 & $\begin{array}{c}\text { Excretion } \\
\left(\mathrm{mg} / \mathrm{kg} \mathrm{W}^{0.75} / \mathrm{d}\right)\end{array}$ & $\begin{array}{c}\text { Excretion } \\
(\%)\end{array}$ & $\begin{array}{c}\text { Retention } \\
\left(\mathrm{mg} / \mathrm{kg} \mathrm{W}^{0.75} / \mathrm{d}\right)\end{array}$ & $\begin{array}{c}\text { Retention } \\
(\%)\end{array}$ \\
\hline $\mathrm{T}_{1}$ & Inorganic (100\% as standard) & $2.79^{a} \pm 0.08$ & $1.62^{\mathrm{a}} \pm 0.05$ & $58.39^{\mathrm{a}} \pm 2.59$ & $1.17^{\mathrm{ab}} \pm 0.06$ & $41.62^{c} \pm 2.45$ \\
\hline $\mathrm{T}_{2}$ & Organic (100) & $2.61^{\mathrm{a}} \pm 0.05$ & $1.22^{\mathrm{b}} \pm 0.06$ & $46.53^{\mathrm{b}} \pm 4.35$ & $1.39^{a} \pm 0.13$ & $53.47^{\mathrm{b}} \pm 0.82$ \\
\hline $\mathrm{T}_{3}$ & Organic (75) & $2.14^{\mathrm{b}} \pm 0.05$ & $1.04^{c} \pm 0.07$ & $48.59^{b} \pm 2.71$ & $1.10^{\mathrm{ab}} \pm 0.04$ & $51.40^{b} \pm 2.65$ \\
\hline $\mathrm{T}_{4}$ & Organic (50) & $1.73^{c} \pm 0.03$ & $0.68^{\mathrm{d}} \pm 0.03$ & $39.18^{\mathrm{bc}} \pm 3.45$ & $1.05^{b c} \pm 0.13$ & $60.81^{\mathrm{ab}} \pm 1.35$ \\
\hline $\mathrm{T}_{5}$ & Cu-Np (75) & $2.08^{\mathrm{b}} \pm 0.04$ & $0.83^{\mathrm{cd}} \pm 0.02$ & $40.05^{\mathrm{bc}} \pm 2.56$ & $1.24^{\mathrm{ab}} \pm 0.04$ & $59.92^{\mathrm{ab}} \pm 1.75$ \\
\hline $\mathrm{T}_{6}$ & Cu-Np (50) & $1.64^{c} \pm 0.06$ & $0.62^{d} \pm 0.19$ & $38.50^{\mathrm{bc}} \pm 2.34$ & $1.02^{b c} \pm 0.05$ & $61.49^{\mathrm{ab}} \pm 2.09$ \\
\hline \multirow[t]{3}{*}{$\mathrm{T}_{7}$} & Cu-Np (25) & $1.14^{\mathrm{d}} \pm 0.02$ & $0.38^{d} \pm 0.18$ & $33.34^{c} \pm 4.36$ & $0.76^{c} \pm 0.02$ & $66.66^{\mathrm{a}} \pm 2.30$ \\
\hline & SEM & 0.056 & 0.033 & 2.126 & 0.037 & 2.141 \\
\hline & $\mathrm{P}$ value & 0.000 & 0.000 & 0.000 & 0.000 & 0.000 \\
\hline
\end{tabular}

$a, b, c, d$ Mean values bearing different superscripts within the column differ significantly $(p<0.05)$. 
Effect of Reduced Dietary Copper Levels Sourced from Organic and Nanoparticles Forms on Performance and Nutrient...

day as well on per cent is significantly $(p<0.05)$ higher in control and linearly reduced in all the treatment groups. Parallel to the excretion, the $\mathrm{Cu}$ retention expressed in $\mathrm{mg}$ per $\mathrm{kg} \mathrm{W}^{0.75}$ as well on per cent was also found significantly $(p<0.05)$ lower in control and linearly increased in all the treatment groups except for $T_{3}$. The excretion was further reduced with reduction of the supplementation either from organic or nano particles of $\mathrm{Cu}$ that may be due to minimum Cu supplemental level in the diet.

The results are closed to our hypothesis that reduced $\mathrm{Cu}$ dietary supplementation level sourced from organic and NP can reduce its excretion rate in dropping to the environment without compromising the chicken performance.

These findings do confirm the better efficiency and bioavailability of organic (Zafar and Fatima, 2018) and nano particles (Patra and Lalhriatpuii, 2019) forms of $\mathrm{Cu}$ as compared to inorganic $\mathrm{CuSO}_{4}$ in the diet resulted by reduction in Cu excretion level of droppings to the environment. Similar results were also reported by many studies (Nollet et al., 2007; Gonzales et al., 2009 and Sawosz et al., 2018).

\section{CONCLUSION}

It was concluded that the organic and nanoparticle forms of $\mathrm{Cu}$ has dose-independent effect on growth, feed intake, feed conversion ratio, nutrient metabolizability, nitrogen and $\mathrm{Cu}$ balance. The dietary inclusion level of $\mathrm{Cu}$ can be reduced to 50 and $75 \%$ and reduce its excretion level when sourced from organic and nano forms, respectively compared to conventional inorganic $\mathrm{CuSO}_{4}$ without compromising the bird's performance.

\section{ACKNOWLEDGEMENT}

The facilities extended by the Department of Poultry Science, Veterinary College, KVAFSU, Bangalore is duly acknowledged. The first author thanks India-Afghan Fellowship Program, Indian Council of Agricultural Research (ICAR), New Delhi for sponsoring his Ph.D. program.

\section{REFERENCES}

Al-Bairuty, G.A., Boyle, D., Henry, T.B., Handy, Sublethal, R.D. (2016). Effects of copper sulphate compared to copper nanoparticles in rainbow trout (Oncorhynchus) at low pH: Physiology and metal accumulation. Aquatic Toxicology. 174: 188-198.

Aminullah, N., Prabhu, T.M., Naik, J., Suresh, B.N., Indresh, H.C. (2021). Performance of Swarnadhara breeder hens supplemented with reduced levels of different copper forms. Veterinary World. 14(5): 1371-1379.

Anjum, N.A., Rodrigo, M.A.M., Moulik, A., Heger, Z., Kopel, P., Zitka, O., Lukatin, A.S., Duarte, A.C., Pereira, E., Kizek, R. (2016). Transport phenomena of nanoparticles in plants and animals/humans. Environmental Research. 151: 233-243.
Collins, J.F., Prohaska, J.R., Knutson, M.D. (2010). Metabolic crossroads of iron and copper. Nutrition Review. 68(3): 133-147.

Das, T., Mondal, M., Biswas, P., Bairagi, B., Samanta, C. (2010). Influence of level of dietary inorganic and organic copper and energy level on the performance and nutrients utilization of broiler chicken. Asian-Australian Journal of Animal Science. 23(1): 82-89.

Ferket, P., Van, H.E., Angel, R. (2002). Nutritional strategies to reduce environmental emissions from nonruminants. Journal of Animal Science. 80: 168-182.

Gonzales, E.A., Fu, C.M., Lu, F.Y., Lien, T.F. (2009). Effects of growth performance and serum traits of piglets. Livestock Science. 126(1-3): 122-129.

ICAR. (2013). Nutrients Requirement of Animal-Poultry. Indian Council of Agriculture Research-New Delhi.

Kozlowski, K., Jankowski, J., Otowski, K., Zdunczyk, Z., Ognik, K. (2018). Metabolic Parameters in young turkeys fed diets with different inclusion levels of copper nanoparticles. Polish Journal of Veterinary Science. 2(21): 245-253.

Nollet, L., Van, J.D., Der, K., Lis, M., Lensing, P., Spring. (2007). The effect of replacing inorganic with organic trace minerals in broiler diets on productive performance and mineral excretion. Journal of Applied Poultry Research. 16(4): 592-597.

Nollet, L.G., Huyghebaert, Spring, P. (2008). Effect of different levels of dietary organic (Bioplex) trace minerals on live performance of broiler chickens by growth phases. Journal of Applied Poultry Research. 17(1): 109-115.

Patra, A. and Lalhriatpuii, M. (2019). Progress and prospect of essential mineral nanoparticles in poultry nutrition and feeding-A Review. Biological Trace Element Research. 197(1): 233-253.

Raje, K., Ojha, S., Mishra, A., Munde, V.K., Rawat, C., Chaudhary, S.K. (2018). Impact of supplementation of mineral nano particles on growth performance and health status of animals: A review. Journal of Entomology and Zoology Studies. 6(3): 1690-1694.

Ramesh, J. (2014). Effect of nanomineral supplementation in TANUVAS smart mineral mixture on the performance of lambs (Doctoral dissertation, Tamil Nadu Veterinary and Animal Sciences University), Chennai, Tamil Nadu, India.

Sarvestani, S.S., Resvani, M., Zamiri, M.J., Shekarforoush, S., Atashi, H., Mosleh, N., (2016). The effect of nanocopper and mannan oligosaccharide supplementation on nutrient digestibility and performance in broiler chickens. Journal of Veterinary Research. 71(2): 153-161.

Sawosz, E., Lukasiewicz, M., Lozicki, A., Sosnowska, M., Jaworski, S., Niemiec, J., Chwalibog, A. (2018). Effect of copper nanoparticles on the mineral content of tissues and droppings and growth of chickens. Archives of Animal Nutrition. 72(5): 396-406.

Scott, A., Prasad, K. andre, V.C., Sawosz, E. (2018). Copper nanoparticles as an alternative feed additive in poultry diet: A review. Nanotechnology Review. 7(1): 69-93. 
Effect of Reduced Dietary Copper Levels Sourced from Organic and Nanoparticles Forms on Performance and Nutrient...

Scott, A., Vadalasetty. K.P., Sawosz, E., Lukasiewicz, M., Vadalasetty, R.K.P. and Jaworski, S., Chwalibog, A. (2016). Effect of copper nanoparticles and copper sulphate on metabolic rate and development of broiler embryos. Animal Feed Science and Technology. 220: 151-158.

Tamilvanan, A., Balamurugan, K., Ponappa, K., Kumar, B.M. (2014). Copper nanoparticles: Synthetic strategies, properties and multifunctional application. International Journal of Nano-Science.13(2): 143.

Usman, M., Zowalaty, E.I., Shameli, M., Zainuddin, K., Salama, N., Ibrahim, M.N.A. (2013). Synthesis, characterization and antimicrobial properties of copper nanoparticles. International Journal of Nanomed. 8: 4467.

Wen, A., Dai, S., Wu, X., Cai, Z. (2019). Copper bioavailability, mineral utilization and lipid metabolism in broilers. Czech Journal of Animal Science. 64(12): 483-490.
Wu, X.Z., Zhang, T.T., Guo, J.G., Liu, Z., Yang, F.H., Gao, X.H. (2015). Copper bioavailability, blood parameters and nutrient balance in mink. Journal of Animal Science. 93(1): 176-184.

Yang, W., Wang, J., Liu, L. (2011). Effect of high dietary copper on somatostatin and growth hormone-releasing hormone levels in the hypothalamic of growing pigs. Trace Element. 143(2): 893-900.

Zafar, M.H. and Fatima, M. (2018). Efficiency comparison of organic and inorganic minerals in poultry nutrition: A review. PSM Veterinary Research. 3(2): 53-59.

Zhu, D., Yu, B., Ju, C., Mei, S., Chen, D. (2011). Effect of high dietary copper on the expression of hypothalamic appetite regulators in weanling pigs. Journal of Animal Feed Science. 20(1): 60-70. 